\title{
Geology, Geochemistry and Geochronology of the Kenticha Rare Metal Granite Pegmatite, Adola Belt, Southern Ethiopia: A Review
}

\author{
Mohammed Seid Mohammedyasin \\ Debre Markos University, Debre Markos, Ethiopia \\ Email:mame1430@gmial.com
}

How to cite this paper: Mohammedyasin, M.S. (2017) Geology, Geochemistry and Geochronology of the Kenticha Rare Metal Granite Pegmatite, Adola Belt, Southern Ethiopia: A Review. International Journal of Geosciences, 8, 46-64.

http://dx.doi.org/10.4236/ijg.2017.81004

Received: December 23, 2016

Accepted: January 21, 2017

Published: January 24, 2017

Copyright $\odot 2017$ by author and Scientific Research Publishing Inc. This work is licensed under the Creative Commons Attribution International License (CC BY 4.0).

http://creativecommons.org/licenses/by/4.0/

\begin{abstract}
This work reviews the geology, geochemistry and geochronology and discusses the spatial and temporal relationship of the granite pegmatite and the rare metal mineralization of the Kenticha granite pegmatite, southern Ethiopia using published and unpublished works to give a comprehensive understanding about the formation of the mineral deposit. The Kenticha rare metal pegmatite belt comprises several groups of pegmatites which show a high magmatic fractionation, regional and compositional zoning, mineralogical assemblage, and secondary alterations. The internal zonation shows high degree of evolution from the border to the core zone during crystallization and solidification of the leucogranitic to pegmatitic melt. Tantalum mineralization at Kenticha includes zoned tantalite-( $\mathrm{Mn})$ and columbite-( $\mathrm{Mn})$, as well as microlite, pyrochlore, uranmicrolite, and rare tapiolite, ixiolite/wodginite and Ta-bearing rutile. The tectonic setting of the Kenticha granite pegmatite in the Within Plate Granite (WPG) to syn-Collisional Granite (syn-COLG) suites and probably sourced from extreme fractionation of syn-to late tectonic granites or anatexis process of the metasedimentary rocks in the area. The emplacement of the Kenticha pegmatite was at ca. $530 \mathrm{Ma}$ and temporally related to the post-collisional phase of granitic magmatism at $570-520 \mathrm{Ma}$, after the last tectonic stage of east African orogeny during the late stage of Gondwana assembly.
\end{abstract}

\section{Keywords}

Geochemistry, Pegmatite, Tantalite, Columbite, Rare Metal Mineralization, Tectonic Setting, Kenticha, Southern Ethiopia

\section{Introduction}

Tantalum is one of the most valuable minerals used in electronic industries, 
super alloys, metal carbides, and in chemical and medical industries. It is one of the five refractory metals which is dark in colour, very hard, ductile, and highly conductive of heat and electricity. Currently, Ethiopia is one of the top ten tantalum producing country which supplies closely $10 \%$ of the world's consumption. The Kenticha pegmatite field is located in the southern Ethiopia and covers an area of ca. $2500 \mathrm{~km}^{2}$ (Figure 1). The pegmatites intrude greenschist to lower amphibolite facies talc-tremolite schists, chromite-bearing serpentinites, and pelitic to graphitic mica schists, emplaced mainly west of NNE-SSW striking Kenticha thrust shear zone. Most of the pegmatites of the Kenticha field strike N-S to

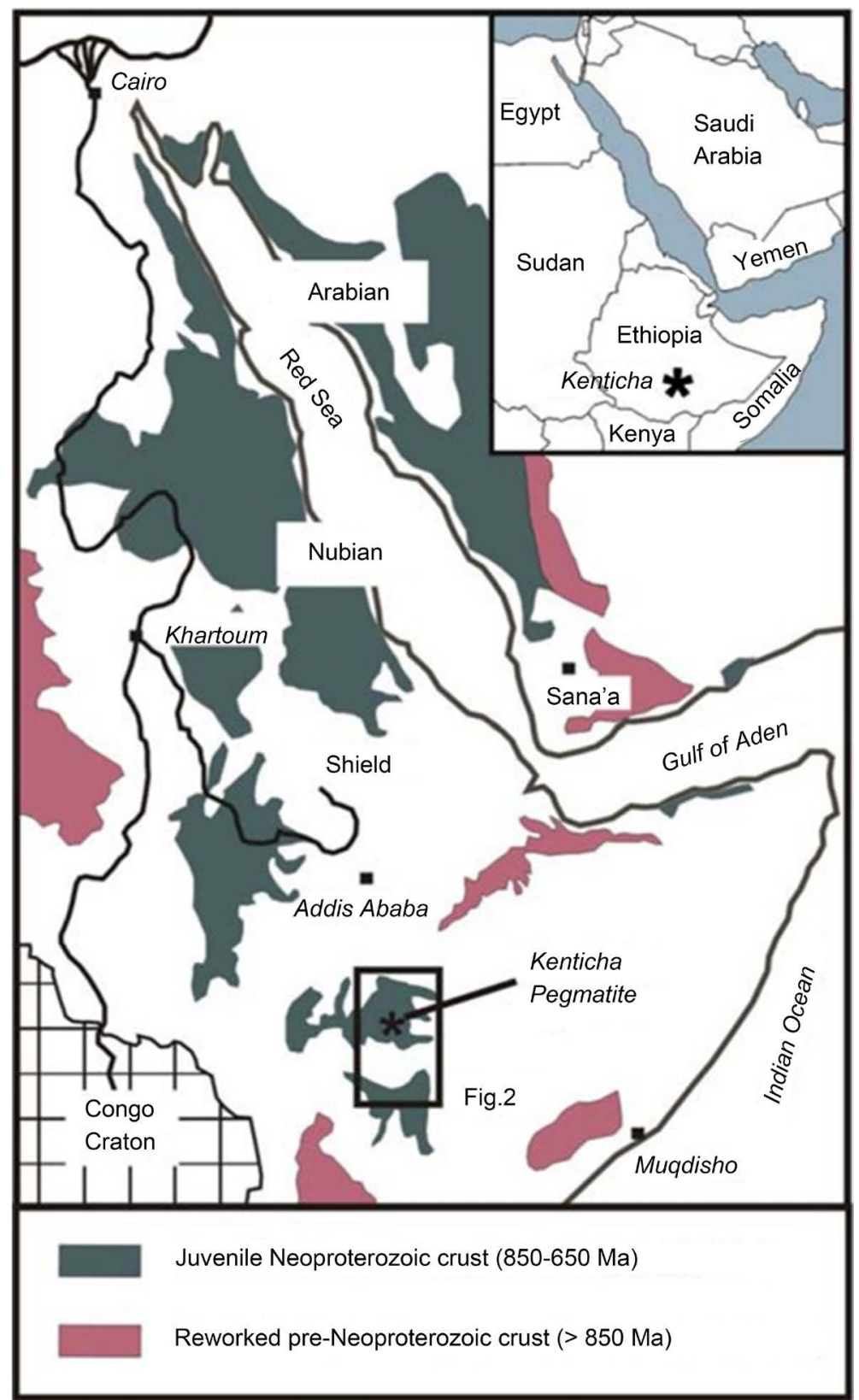

Figure 1. Geological sketch map of northeastern Africa and Arabia showing major crustal segments and the locations of tantalum deposits and mineralization, including the Kenticha Pegmatite. 
NNE-SSW which display considerable size differences, internal zoning, mineralogy and geochemistry [1].

This work reviews the geology, geochemistry and geochronology and discusses the spatial and temporal relationship of the granite pegmatite and the rare metal mineralization of the Kenticha granite pegmatite, southern Ethiopia using published and unpublished works to give a comprehensive understanding about the formation of the rare metal deposit within the frame work of the regional geological and tectonic setting.

\section{Geological and Tectonic Setting}

The Arabian-Nubian Shield (ANS), in the northern part of the East African Orogen (EAO), is developed through horizontal crustal accretion during the closure of the Mozambique Ocean as recognized from ophiolites and their dismembered fragments, and chemically distinct island-arc volcanic and plutonic complexes (Figure 1; [2]). The suture zones of the ophiolite suites further traced in the Mozambique Belt provide evidence that they were formed by orogenic mechanism. The N-S trending southern ANS arc-arc sutures (Barsaloi-Tuludimtu-Baraka sutures and Galana-Adola-Moyale-Ghedem-Arag-sutures), partly flanked by migmatic gneiss terranes, might represent either pre-Neoproterozoic crust or roots of Neoproterozoic arcs [3]. Wrench tectonics in the region concentrated along two shear belts, i.e., western Barka Sinistral Shear Zone which is probably northern extension of Tuludimtu Belt and the Eastern Ghedem-Araq Shear Belt (Asmara-Nakfa Shear Belt) to the east a continuation of the Adola-Moyale Belt [4].

Following the amalgamation of Gondwana (680 - $640 \mathrm{Ma})$, the proto-Arabian Nubian Shield is affected by regional exhumation, erosion and subsidence. Granitic magmatism ( 610 Ma onward) was occurred by increasing the amounts of alkali-feldspar granite and alkali granite [5]. Juvenile crust and (or) depleted mantle are magma sources of Late Cryogenian-Ediacaran granitoids, mostly originated in anorogenic, post-collisional, commonly extensional settings. The crusts were formed by melting and fractionation of (a) anhydrous high-grade metamorphosed lower crust, mafic-to intermediate calc-alkaline crust, and (or) (b) subduction-modified mantle wedges associated with slab break-off or delamination [5]. Further granitic magmatism was continued until $565-560 \mathrm{Ma}$ and the East African Orogeny ceased by $550 \mathrm{Ma}$. Most of geochemical data came from granitoids in the ANS have indicated the early magmatic calc-alkaline granitoids are formed within evolving arc setting [6]. The youngest late- to postcollisional alkaline suite granitoids have formed during the decay of the previously consolidated orogon, possibly involving sub-continental lithospheric delamination [5] [7].

The Precambrian geology of southern Ethiopia consists of two distinct lithotectonic terranes: (a) the granite-gneiss terrane, consisting of high-grade para- and orthogneisses and deformed to metamorphosed granitoids, biotite-hornblende gneiss and amphibolite and (b) the ophiolitic fold and thrust belts, consisting of 
low-grade, mafic-ultramafic and sedimentary assemblages. The granitoids compositionally ranges from undiformed to foliated diorite to granites [8]-[13]. The volcanosedimentary ophiolite suites are composed of mafic and ultramafic metasedimentary rocks, which represent the Cryogenian arc-arc sutures overprinted by Ediacaran deformation [14]. The low-grade metamorphic volcano-sedimentary unit consists of amphibolite, carbonaceous quartz-mica schist, chlorite-actinolite schist, quartz-feldspar-biotite schist, metaconglomerate, graphitic quartzite and mafic to ultramafic bodies.

The Adola Belt and the surrounding southern Ethiopia has been divided into Lower, Middle and Upper Complexes [15] [16] [17] [18]. The Lower Complex comprises the Archaen cratonic basement of high-grade gneisses and migmatites with subordinate quartz-feldspathic gneisses and schists. The Middle Complex covered by platforms of psammitic and pelitic metasediments with minor marbles and schists of Lower to Middle Proterozoic age and the Upper Complex of Neoproterozoic age consist low grade, predominantely greenschist facies, volcanosedimentary ophiolitic assemblages [18]. However, geochronological and isotopic studies defined the Precambrian basement rocks of the southern Ethiopia is dominantly Neoprotrozoic in age [19] [20] [21] [22] and the Archean or preNeoproterozoic rocks appreciably are part of pre-Neoproterozoic continental fragments [23].

The Adola Belt includes the Aflata and Kenticha Formations, Adola orthometamorphic rock series and early Paleozoic post orogenic granites and pegmatites from older to younger, respectively. The Kenticha Formation is found in a narrow synclinal structure comprising biotite-, muscovite-, garnet amphibolite- and quartz-feldspatic-gneisses, fine grained amphibolite-, staurolitegarnet-biotite-, garnet-staurolite- and two-mica-schists, and marble in the order of older to younger ages [24] [25].

\section{The Kenticha Rare Metal Pegmatite Field}

\subsection{Granites}

The Kenticha granite pegmatite field comprises monominiralic quartz, spodumene pegmatite, muscovite pegmatite, blocky microcline and muscovite-albite granite. The postorogenic granites are mainly composed of reddish and gray biotite granite and are high-K calcalkaline and highly siliceous. There are three different types of granites i.e., biotite granite, two mica granite and alaskitic granite. Their order of emplacement is biotite granite, two-mica granite, alaskitic granite, Albite + sericite + microcline + greisens + amazonite and finally pegmatites from older to younger. The alaskitic granites and the pegmatite bodies are injected as magmatic dikes into the host-rocks. This granite is characterized by lack of biotite, replacement of albite by K-feldspar and muscovite, and enrichment in quartz, $\mathrm{Nb}, \mathrm{Ta}, \mathrm{Rb}, \mathrm{Cs}, \mathrm{Li}$ and $\mathrm{Sn}$ and depleted in aluminium, titanium, magnesium, calcium, potassium, iron oxides, $\mathrm{Sr}, \mathrm{Ba}$, and $\mathrm{Zr}$ than the biotite and two-mica granites [26] [27]. It also shows alteration such as sericitization, albitization and kaolinization, and solution infiltration [27]. 


\subsection{Regional and Compositional Zonings}

Regional zoning of series of N-S trending barren to rare-metal enriched granite pegmatites in the area can be classified into five different types of pegmatites based on their geological and geochemical signatures [26] [29] [30]. These are (a) barren pegmatites, (b) Ta-poor pegmatites (Kilkele II and III, and Bupo II), (c) Ta-rich beryl-columbite subtype (Kilkele I and Dermidama), (d) complex spodumene type, and (e) albite spodumene type (Bupo I) (Figure 2). The regional zoning is also described in similar mineralogy, composition and texture with the above classification. Simple description as spodumene type for Kenticha rare metal pegmatite would not fit since it also consists of Li-silicates accommodated in lepidolite, spodumene, holmquistite, albite and swinfordite and Li-phosphates existed in the form of amblygonite and lithiophyllite [31]. Numerous veins and dikes in Kenticha show inward mineralogical and textural changes in an increasing in complexity parallel to the degree of pegmatite fractionation [29]. Such zoning and mineralogical changes from the rime to the core zones are caused by inward crystallization of hydrous magma [32] [33]. Consequently, inward changes in mineralogy is recognized from sodic aplite,

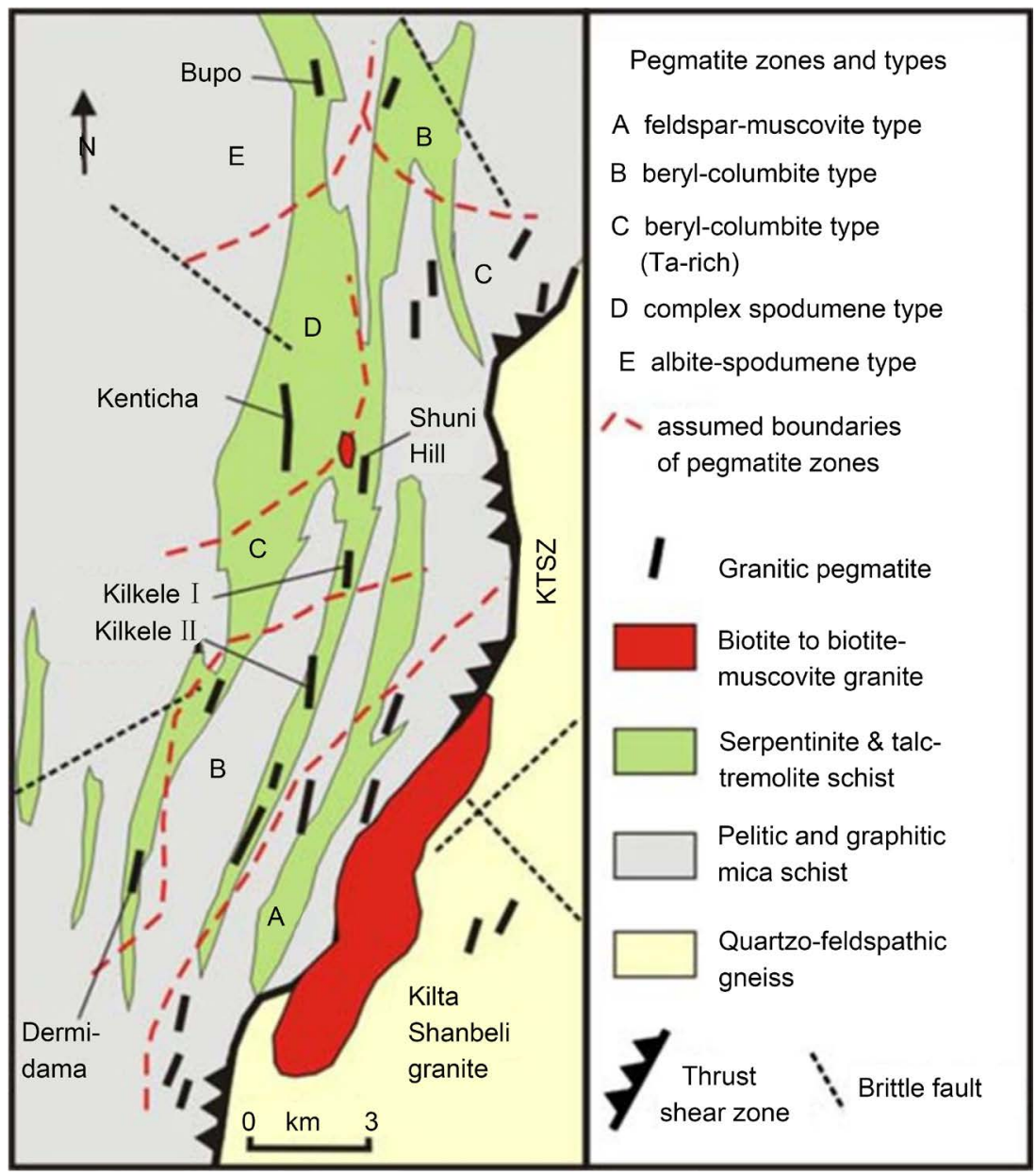

Figure 2. Central part of Kenticha rare metal pegmatite field and regional pegmatite zoning (modified from Desta et al. [33]). See this location of this figure on Figure 1. 
microcline-quartz-albite zone followed by quartz-muscovite-albite-spodumene zone to lenticular masses of greisen, lepidolite and quartz core units.

Different types of compositional zoning in Kenticha granite pegmatite such as oscillatory, patchy and mixed oscillatory has been identified [30]. The oscillatory zoning is developed as result of repetitive variations related to crystal growth processes, concentration of the major elements, segregation of gas-saturated magma and is consistent with the periodic variation in $\mathrm{Ta}, \mathrm{Nb}, \mathrm{Mn}$ and Fe contents. The texture of this zoning is manifested by relatively homogeneous core, zoned mantle and faceted border zone. The patchy zoning and other replacement textures of columbite-tantalite are formed by late-coming gaseous-rich chemical fluids resorption and replacement processes [30]. The late generation by replacement processes are relatively rich in $\mathrm{Ta}$ and $\mathrm{Mn}$.

The Kenticha granites are compositionally peraluminous and fertile with varieties of minerals such as biotite, muscovite, tourmaline, spessartine, almandine, corderite and topaz. The Kenticha rare metal pegmatite belt comprises several groups of pegmatites which shows a fractionation trend. In situ fractionation of subhorizontal pegmatite sheet at Kenticha accounts for chemical and mineralogical zoning. The crystallization was occurred under closed system and contamination with the ultramafic host-rocks from the hangingwall was during postmagmatic hydrothermal stages [28]. Results of major and trace element analysis and their trends in ore, accessary and rock forming minerals suggest that these groups of granite-pegmatites are cogenetic in nature [26].

\subsection{Paragenetic Associations, Alterations and Rare Metal Mineralization}

The primary ore deposit (below $60 \mathrm{~m}$ depth) shows complex internal structure and variety of alternating paragenetic associations. The bottom of this ore body is muscovite and two-feldspar granite that grades upward into albite, muscovite-quartz-microcline and muscovite-quartz-albite-microcline pegmatite zones. The middle zone is dominated by muscovite-spodumene-microcline-albite pegmatite superimposed with albitized and greisenized linear units. The upper zone is the most differentiated pegmatite with spodumene, large quartz cores, microcline and ambigonite montebrasite blocks, and spodumene-quartz zones. The last stage of paragenesis dominated hydrothermally metasomatized mineral associations such as (a) fine to very fine grained and inequigranular tabular albites, (b) cleavalendite, (c) small flaky and coarse-flaky pink coloured Li-bearing muscovites, (d) lepidolite-quartz, and (e) quartz-albite and quartz-albite-muscovite associations [34]. Segregation of cleavalendite and lepidolite-qaurtz complex zones, and greizenized quartz cores and blocky microcline develop high amount of Ta contents in the metasomatically altered upper zones.

Similarly, the Ta content in the weathering mantle ore (above $60 \mathrm{~m}$ depth) is very high in metasomatic mineral associations and characterized by pronounced albitization and greisenization. While the low Ta content is found in ores associated with granite, muscovite-microcline-albite zones, and blocky microcline. 
The Ta content is also increased upward from bottom to top. Ta is associated with the columbite-tantalite group minerals forming flattened and short prismatic small grain crystals of $5-7 \mathrm{~cm}$ length [35].

\section{Geochemistry}

The Kenticha granite pegmatites (Figure 3) are endowed of rare metal mineralization including tantalite, columbite, beryl and other accessory minerals.

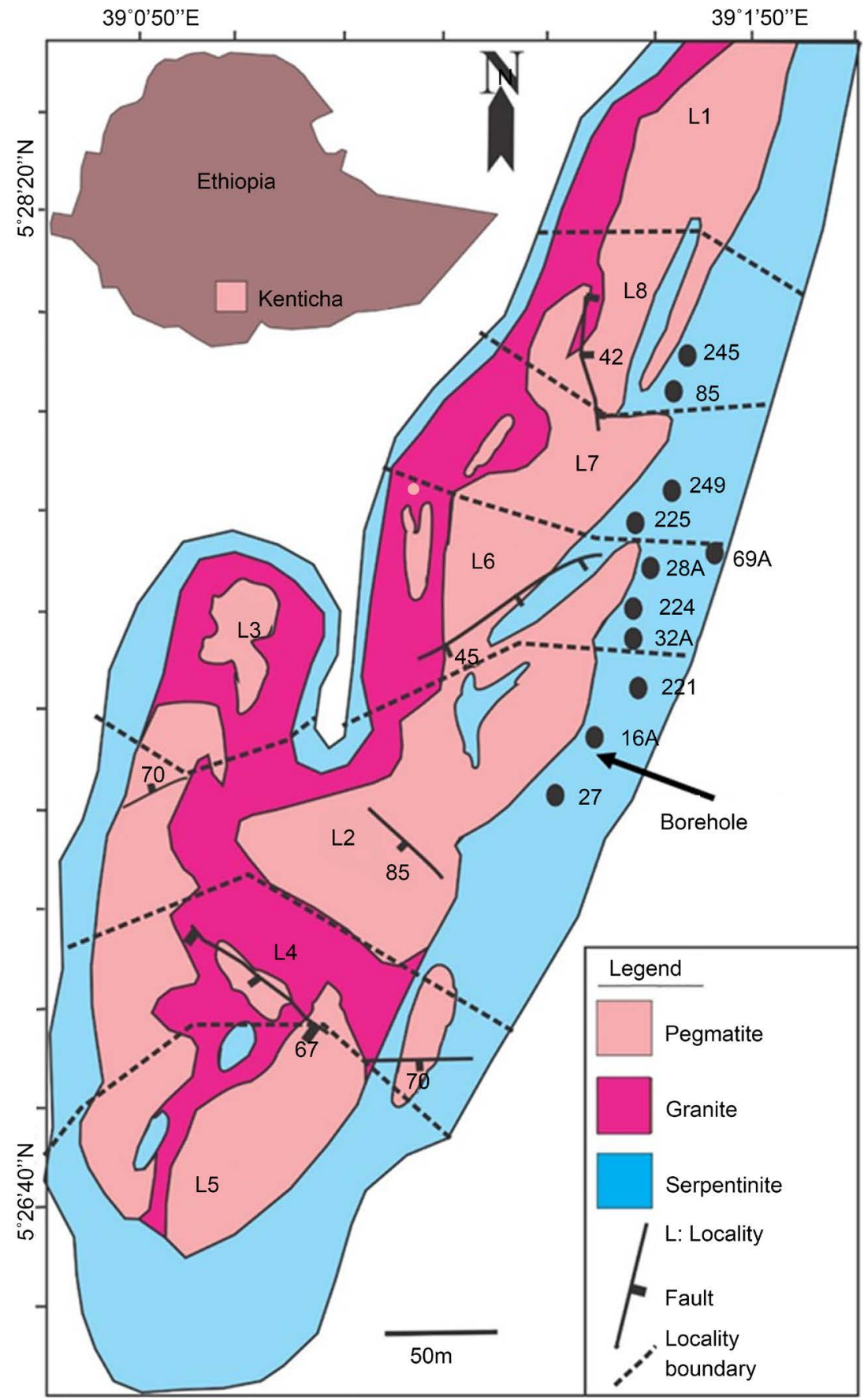

Figure 3. Simplified geological sketch map of the Kenticha pegmatite with location of sampled boreholes [36]. See the location of this figure on Figure 2. 
Whole-rock geochemistry of drill core samples, muscovite chemistry, and CGM compositional variation all demonstrate a highly differentiated magma [28] [36]. These data shows internal zonation with high degree of evolution from the border to the core zone during crystallization and solidification of the leucogranitic to pegmatitic melt [28].

Tantalum mineralization at Kenticha includes zoned tantalite-(Mn), columbite-(Mn), and minor microlite, pyrochlore, uranmicrolite, rare tapiolite, ixiolite/wodginite and Ta-bearing rutile. Columbite-tantalite group minerals (CGM) compositions from Kenticha follow a trend from columbite-(Fe)-columbite-(Mn) to tantalite-(Mn) (Figure 4; [28] [36]). Concentrates of tantalum-niobium oxides (TNO) from the plant contain on average 79\% composed of CGM, pyrochlore-supergroup minerals, rare tapiolite and wodginite $(<0.1 \%$ each) [37]

The whole-rock geochemical composition of the Kenticha pegmatite corresponds to a peraluminous highly silicic leucogranite, strongly enriched in lithophile elements, especially $\mathrm{Li}, \mathrm{Rb}, \mathrm{Cs}, \mathrm{Ga}$, and $\mathrm{Ta}$ [28] [36]. The Kenticha granite pegmatite is typical of strongly differentiated granites with $\mathrm{Rb}$ enrichment and low $\mathrm{Ba}$ and $\mathrm{Sr}$ contents (Figure 5). This is related to the magma differentiation, feldspar normative and their $\mathrm{Rb}, \mathrm{Ba}$ and $\mathrm{Sr}$ affinities [38]. Most of the

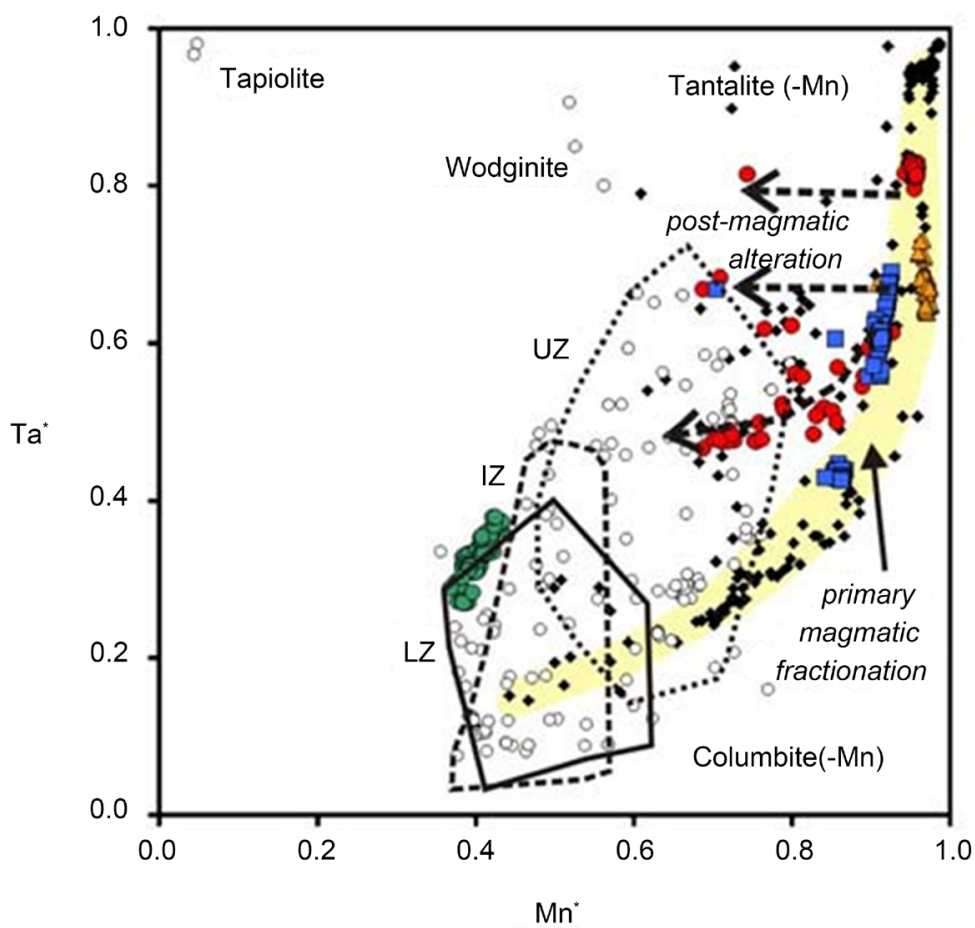

\footnotetext{
- Kenticha plant concentrates

- Kenticha drill core samples

$\Delta$ Kenticha UZ spodumene unit (open pit)

- Kenticha UZ quartz unit (open pit)
}

- Bupo pegmatite

- Shuni Hill pegmatite

Figure 4. CGM Variation diagram of $\mathrm{Mn}^{\star}\left(\mathrm{Mn} /(\mathrm{Mn}+\mathrm{Fe}){ }^{\star} 100\right)$ and $\mathrm{Ta}{ }^{\star}(\mathrm{Ta} /(\mathrm{Ta}+\mathrm{Nb})$ * 100) in CGM of the main Kenticha pegmatite rare-metal field [28]. Where LZ: lower (border) zone, IZ: intermediate zone and UZ: upper (core) zone. 


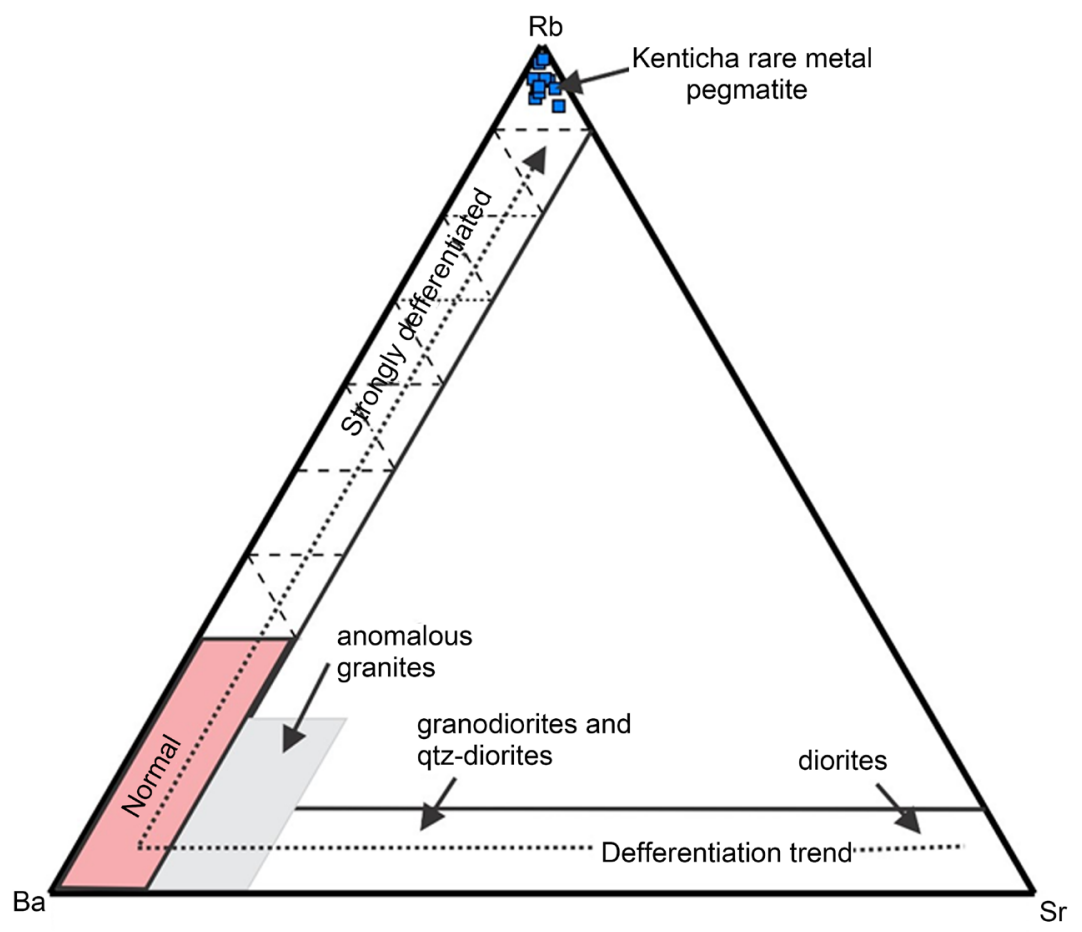

Figure 5. Rb-Ba-Sr plot of El Bouseily and El Sokkary [39] for granitic rocks. It indicates a granitic trend typical of strongly differ-entiated granites with $\mathrm{Rb}$ enrichment and low $\mathrm{Ba}$ and Sr contents for whole-rock analyses of the Kenticha drill core samples [36].

Kenticha whole-rock samples show Cs-enrichment (upto 565 ppm; [28]).

The Kenticha, Bupo and Shuni Hill pegmatites show distinct difference in REE patterns in CGM (Figure 6). This could be arise as result of (a) formation of CGM in different zones and at different stages of fractionation within the pegmatite(s), (b) abundance and nature of coexisting REE-incorporating minerals, or (c) different sources of the pegmatite melts.

\section{Discussion}

\subsection{Age and Emplacement of Pegmatites}

Uranium-lead age dating indicate that the emplacement of the Kenticha pegmatite was at ca. $530 \mathrm{Ma}$ and temporally related to the post-collisional phase of granitic magmatism at $570 \mathrm{Ma}-520 \mathrm{Ma}$ [41]. On the other hand the country/host-rocks are dated $\sim 580 \pm 50 \mathrm{Ma}-680 \pm 30 \mathrm{Ma}$ [30]. The emplacement of Kenticha and Bupo pegmatite is coeval and temporally related to postorogenic granite magmatism [10] [41] [42]. The intrusions of two-mica and alaskitic granites and the associated pegmatite swarms followed the regional fault system (Figure 7). The emplacement of pegmatites is controlled by folded and faulted structures trending N-S which could be related to the final stage of Katangan tectonogenesis [25] [43]. This forms the Kenticha Synclinal rare metal belt [26]. Thus, the evolution the Kenticha granite pegmatite start after the last tectonic stage of east African orogeny, i.e., post collision stage at ca. $620 \mathrm{Ma}-590 \mathrm{Ma}$ [14] [44] [45] [46]. 


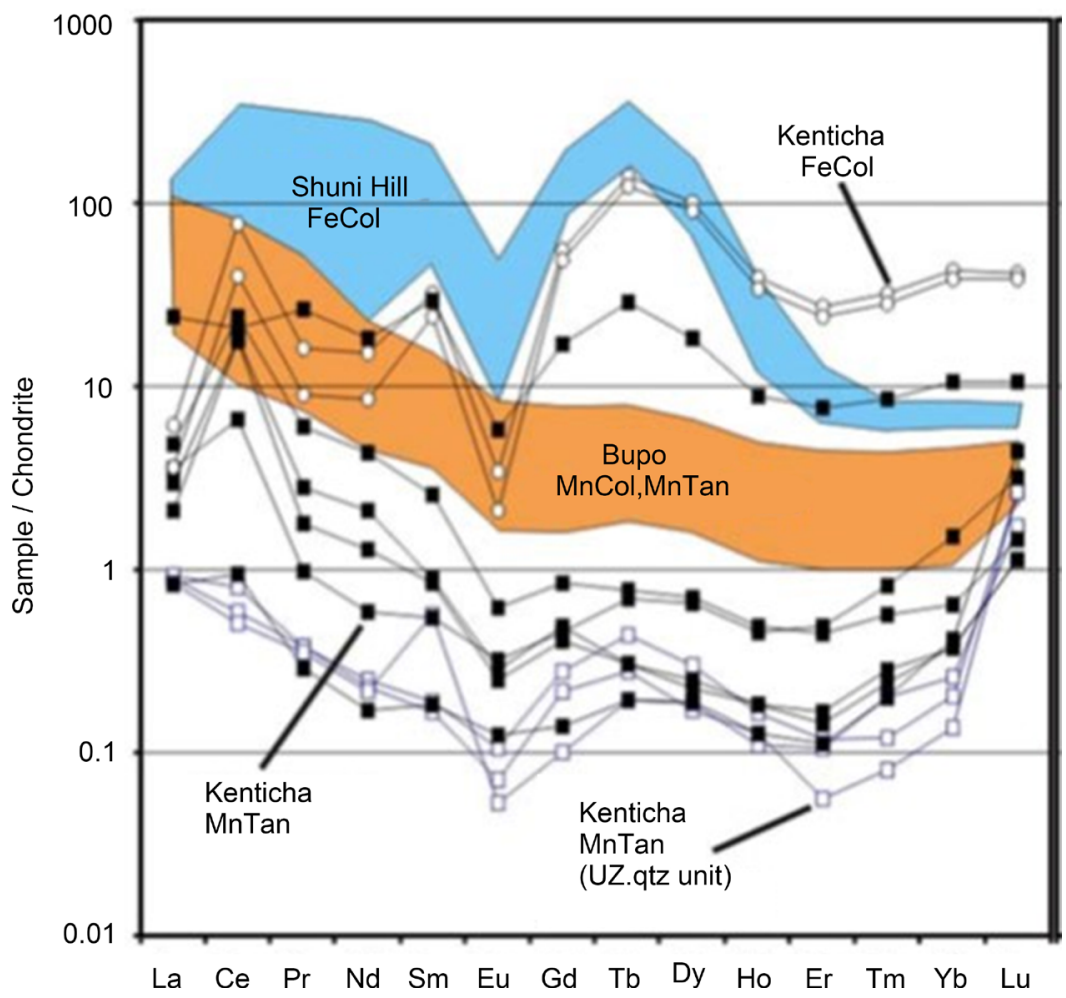

Figure 6. Chondrite normalized REE concentrations in columbite-tantalite from Kenticha, Bupo, and Shuni Hill pegmatites. Normalization factors are from McDonough and Sun [40]. The Kenticha samples were collected from the processing plant and from the outcropping orebody (UZ quartz unit) [28]. Where FeCol: columbite-(Fe), MnCol: columbite(Mn), MnTan: tantalite-(Mn).

The deep-seated faults are controlling the rare metal mineralization and the emplacement of the pegmatites (Figure 7(a)). Besides the deep-seated normal faults there are also minor normal faults that are trending NW-SE and NE-SW direction varying in their dip angle and direction. The orientation of the joint sets and the minor faults is similar which imply that the jointing was related with the minor faulting events. They all are striking NNW-SSE and NW-SE and dipping NNE and NE directions, respectively (see Figures 7(b)-(e)).

Numerous joints also observed in the area though currently they are obstructed by the mining activity. Tadesse (1998) grouped these joints into eight joint sets where their average strike varies from 30 to 60 relatively with higher dip amount and 170 to 277 relatively with lower dip amount [47].

\subsection{Tectonic Setting}

The Kenticha granite has been interpreted as Volcanic Arc Granite (VAG) and is related to subduction volcanism by Tadesse [29]. However, Mohammedyasin [36] interpreted as Within Plate Granite (WPG) to syn-Collisional Granite (syn-COLG) granite using whole rock geochemical analysis. Mohammedyasin [36] further proposed that the Kenticha granite pegmatite is probably sourced from (a) extreme fractionation of syn-to late tectonic granites (e.g., [33]) or (b) anatexis process or in-situ partial melting of the metasedimentary rocks in the 


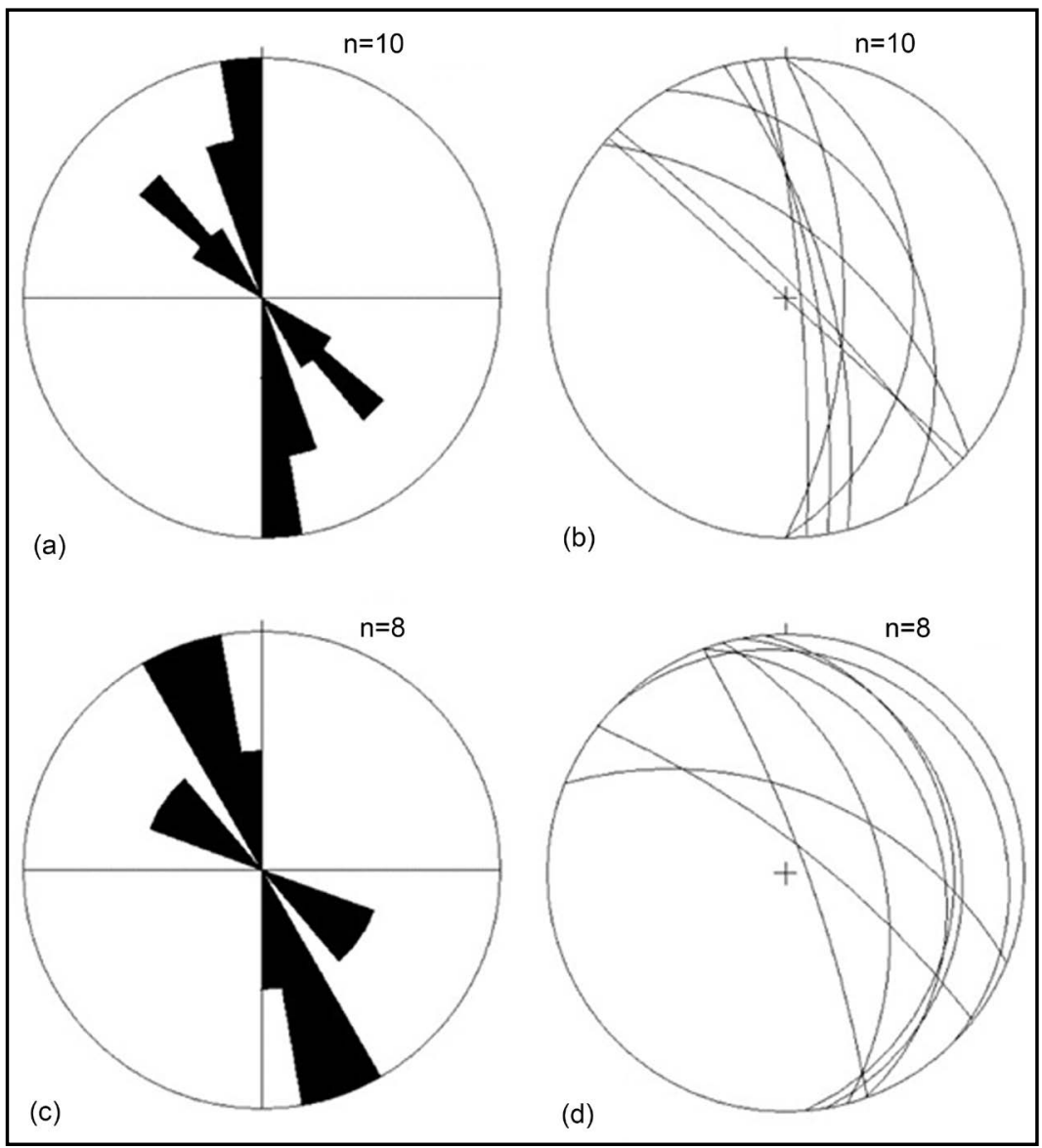

Figure 7. The attitude of faults and joint sets; (b \& d) rose diagram and (c \& e) equal area stereographic projection of the minor normal faults and joint sets, respectively. The faults and joints have similar strike and dip directions.

area [48] [49].

\subsection{Origin of Rare Metal Bearing Granite Pegmatites}

Among the various proposed models that explain the formation of pegmatites (a) the fractional crystallization of the melt and (a) interaction of aqueous fluid with the melt are the two competing models [50]. The concentration of fluxing components and other incompatible elements increase towards the centre of the magma chamber as crystallization proceeds resulting increasing chemical fractionation from the margin to the centre of the pegmatites [51]. The formation of giant crystals and exotic minerals however can be evidenced for the interaction of fluids and the melt by alkalis incongruent partitioning [52] such as the aqueous fluids enriched in $\mathrm{K}$, and the melt enriched in Na. Later, the model of buoyant ascent, has been proposed by Jahns [53] in order to explain the chemical fractionation of the pegmatites.

Two end member models have been proposed for the formation of fertile pegmatites i.e., continuous crystallization and partial melting. Continuous crystallization of pre-existing parental rocks by partial melting which homogenize in a collective reservoir produces variety of granitic magmas depending on the de- 
gree of fractional crystallization. The varying degree of partial melting produces wide compositional variation of granite magmas. Partial melting of compositionally distinct protoliths can also produce wide compositional spectrum of granite magmas with the same degree of partial melting. This could be arise from the change mineralogy, trace element chemistry, mineral stability field of sheet silicates or accessory minerals and their content in the mineral/residuum phase, and metasomatic alteration of the source metasedimentary lithology [54].

Partial melting of mica rich pre-existing metamorphic rocks in collisional zones commonly forms LCT granitic pegmatites and gives high concentration of trace and rare earth elements. Muscovite and biotite carry most of the trace elements. Abundant muscovite schist of marine sedimentary origin react extensively at the onset of anatexis [50]. Consequently, large fractions of the rare element content transferred to the initial small volume of partial melt. The melting reaction of muscovite and biotite also produce K-feldspar with some amount of alumunosilicate and spinel under low $\mathrm{H}_{2} \mathrm{O}$ saturation condition (e.g., [55]) of rubidium, slightly incompatible in $\mathrm{K}$-feldspar. The ratio of $\mathrm{Li}$ and $\mathrm{Cs}$, which are compatible elements in K-feldspar, is elevated as compared to $\mathrm{Rb}$ during consecutive crystallization resulting rare-alkali enrichment [56].

\subsection{The Origin of the Kenticha Granite Pegmatite}

The formation of rare-element granitic pegmatites is of mainly by fractional crystallization of a granitic melt [57] [58] [59]. Partial melting of appropriate composition (e.g., [54]) such as metasedimentary Mn-bearing exhalites also proposed for the formation of these pegmatites [48]. From the tectonic setting, the Kenticha granite probably sourced from (a) extreme fractionation syn- to late tectonic granites (e.g., [33]) or (b) anatexis process or in-situ partial melting of the metasedimentary rocks in the area [48] [49]. The genesis of the Kenticha pegmatite is similar with the Harney Peak and Tin Mountain granite pegmatites, Black Hills (South Dakota) and Ponta Negra, Brazil which is by partial melting of metasedimentary rocks with further strong fractional crystallization [32] [48] [54]. Besides, their tectonic setting is similar and related to post stage Gondwana assembly. Some of the data point also plotted in the limit and to the syn-collisional granite. This further indicates the formation of granite pegmatite can be also partly related to post-collisional processes during the post Gondwana assembly.

The relict textures in minerals such as relict of garnet in the studied samples can suggest for anatectic origin of granitic pegmatite [60]. The other evidence is the age of the Kenticha pegmatite (ca. $530 \mathrm{Ma}$; [41]) which is bracketing with the time interval of Gondwana assembly and related to the collapse magmatism in the region (ca. 580 - $520 \mathrm{Ma}$; [61]). Heilbron et al. [61] pointed out the heat that triggered this magmatic event could still be a consequence of the collisional orogeny. Küster et al. [41] also described that the Kenticha pegmatites are temporally related to the post-collisional phase of granitic magmatism (570 - 520 Ma). Uranium-Lead dating for the Kenticha tantalite in the spodumene zone 
gave an age of ca. $520 \mathrm{Ma}$. Based on age, the Kenticha pegmatite is formed after the cease of East African Orogeny ( $550 \mathrm{Ma}$; [5]). This further implies the origin of the granite and granite pegmatite is from an attenuated continental crust, not from an oceanic island granite [36].

The increase in basal heat flow by ascending magmatic intrusion or collision causes partial melting of the pre-existing metasedimentary rocks. The later case is more reseanable for the Kenticha pegmatites since they are sturcurally located at a shear zone. During the ascent of the magma fractional crystalization and assimilation with the country rocks result different zonal mineral assemblages, geochemical variations and rare metal mineralizations (Figure 8). The ascent of the magma further could allow to melt the country rock which modify the composion of the magma. The incompatible elements such as $\mathrm{Ta}$ and $\mathrm{Nb}$ concequentely separate in the late stage of fractional crystalization. Fractionated compositions of pegmatite magmas and their final aqueous fluids are highly reactive with less-evolved to wall zone and host-rocks [62] [63]. Local contamination is occurred during the emplacement of the pegmatites along dike margins (metasomatic zone), and at the transition into sub-solidus conditions (Figure 8).

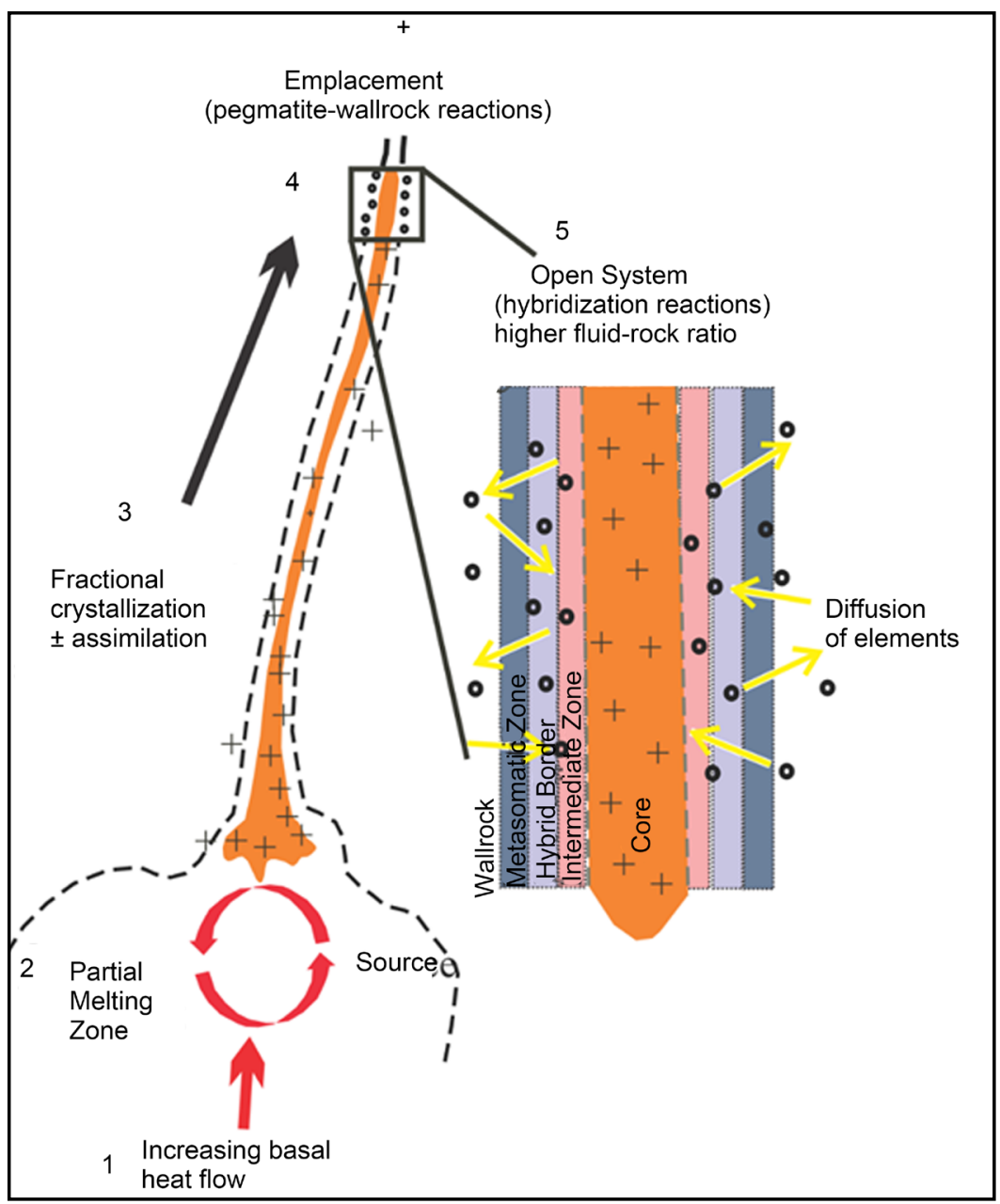

Figure 8. Conceptual diagram to illustrate the genesis of the Kenticha pegmatite (modified from McKeough et al. [64]). 
The parent rock for granites and pegmaite is probably the metasedimentary rocks which form felsic magma during the increase in temperature triggered by the collision orogeny.

\section{Conclusions}

The Kenticha rare element granites: biotite, two-mica and alaskitic granites and pegmatites intrude greenschist to lower amphibolite facies, talc-tremolite schists, chromite-bearing serpentinites, and pelitic to graphitic mica schists, emplaced mainly west of NNE-SSW striking Kenticha thrust shear zone. Regional zoning of series of N-S trending pegmatites with compositional varation from barren to rare-metal enriched granite pegmatites are observed in the area. Tantalum mineralization at Kenticha includes zoned tantalite-( $\mathrm{Mn})$, columbite-(Mn), as well as microlite, pyrochlore, uranmicrolite, rare tapiolite, ixiolite/wodginite and Ta-bearing rutile. The Kenticha pegmatite is a peraluminous highly silicic leucogranite, strongly differentiated and enriched in lithophile elements, especially $\mathrm{Li}, \mathrm{Rb}, \mathrm{Cs}, \mathrm{Ga}$, and $\mathrm{Ta}$, and deplated in $\mathrm{Ba}$ and $\mathrm{Sr}$.

The Ta content in the weathering mantle ore is very high in metasomatic mineral associations and characterized by pronounced albitization and greisenization. While the low Ta content is found in ores associated with granite, muscovitemicrocline-albite zones, and blocky microcline. The Ta content is also increased upward from bottom to top (core zone). The primary ore deposit shows complex internal structure and variety of alternating paragenetic associations. The bottom of this ore body is muscovite and two-feldspar granite that grades upward into albite, muscovite-quartz-microcline and muscovite-quartz-albite-microcline pegmatite zones. The middle zone is dominated by muscovite-spodumene-microclinealbite pegmatite superimposed with albitized and greisenized linear units. The upper zone is the most differentiated pegmatite with spodumene, large quartz cores, microcline, ambigonite-montebrasite blocks and spodumene-quartz zones. The last stage of paragenesis has been dominated by hydrothermally metasomatized mineral associations.

The tectonic setting of the Kenticha granite pegmatite is in the Within Plate Granite (WPG) to syn-Collisional Granite (syn-COLG) suites and probably sourced from (a) extreme fractionation of syn-to late tectonic granites or anatexis process of the metasedimentary rocks in the area. The emplacement of the Kenticha pegmatite was at ca. $530 \mathrm{Ma}$ and temporally related to the post-collisional phase of granitic magmatism at $570-520 \mathrm{Ma}$, after the last tectonic stage of east African orogeny during the late stage of Gondwana assembly.

\section{Acknowledgements}

I appreciate the previous authors for their contributions used in this work.

\section{References}

[1] Poletayev, J., Verbvsky, O., Teweldemedhin, T., Musa, E., Alemayehu, B. and Manaye, Y. (1991) The Geology and Rare Metal Potential of the Kenticha Pegmatite 
Deposit. Internal Report (unpubl) Ethiopian Mineral Resource Development Corp, Ministry of Mines and Energy, Addis Ababa.

[2] Kusky, T.M., Abdelsalam, M., Tucker, R.D. and Stern, R.J. (2003) Evolution of the East African and Related Orogens, and the Assembly of Gondwana. Precambrian Research, 123, 81-85. https://doi.org/10.1016/S0301-9268(03)00062-7

[3] Stern, R.J., Ali, K.A., Abdelsalam, M.G., Wilde, S.A. and Zhou, Q. (2012) U-Pb Zircon Geochronology of the Eastern Part of the Southern Ethiopian Shield. Precambrian Research, 206-207, 159-167. https://doi.org/10.1016/j.precamres.2012.02.008

[4] Ghebreab, W., Greiling, R.O. and Solomon, S. (2009) Structural Setting of Neoproterozoic Mineralization, Asmara District, Eritrea. Journal of African Earth Sciences, 55, 219-235. https://doi.org/10.1016/j.jafrearsci.2009.05.001

[5] Johnson, P.R., Andresen, A., Collins, A.S., Fowler, A.R., Fritz, H., Ghebreab, W., Kusky, T. and Stern, R.J. (2011) Late Cryogenian-Ediacaran History of the ArabianNubian Shield: A Review of Depositional, Plutonic, Structural, and Tectonic Events in the Closing Stages of the Northern East African Orogen. Journal of African Earth Sciences, 61, 167-232. https://doi.org/10.1016/j.jafrearsci.2011.07.003

[6] Hargrove, U.S., Stern, R.J., Kimura, J.I., Manton, W.I. and Johnson, P.R. (2006) How Juvenile Is the Arabian-Nubian Shield? Evidence from Nd Isotopes and PreNeoproterozoic Inherited Zircon in the Bi'r Umq Suture Zone, Saudi Arabia. Earth and Planetary Science Letters, 252, 308-326. https://doi.org/10.1016/j.epsl.2006.10.002

[7] Farahat, E.S., Mohamed, H.A., Ahmed, A.F. and El Mahallawi, M.M. (2007) Origin of I-and A-Type Granitoids from the Eastern Desert of Egypt: Implications for Crustal Growth in the Northern Arabian-Nubian Shield. Journal of African Earth Sciences, 49, 43-58. https://doi.org/10.1016/j.jafrearsci.2007.07.002

[8] Abdelsalam, M.G., Tsige, L., Yihunie, T. and Hussien, B. (2008) Terrane Rotation during the East African Orogeny: Evidence from the Bulbul Shear Zone, South Ethiopia. Gondwana Research, 14, 497-508. https://doi.org/10.1016/j.gr.2008.05.001

[9] Tsige, L. (2006) Metamorphism and Gold Mineralization of the Kenticha-Katawicha Area: Adola Belt, Southern Ethiopia. Journal of African Earth Sciences, 45, 16-32. https://doi.org/10.1016/j.jafrearsci.2006.01.002

[10] Worku, H. and Schandelmeier, H. (1996) Tectonic Evolution of the Neoproterozoic Adola Belt of Southern Ethiopia: Evidence for a Wilson Cycle Process and Implications for Oblique Plate Collision. Precambrian Research, 77, 179-210.

https://doi.org/10.1016/0301-9268(95)00054-2

[11] Worku, H. and Yifa, K. (1992) The Tectonic Evolution of the Precambrian metamorphic Rocks of the Adola Belt (Southern Ethiopia). Journal of African Earth Sciences, 14, 37-55. https://doi.org/10.1016/0899-5362(92)90054-G

[12] Yibas, B., Reimold, W.U., Armstrong, R., Koeberl, C., Anhaeusser, C.R. and Phillips, D. (2002) The Tectonostratigraphy, Granitoid Geochronology and Geological Evolution of the Precambrian of Southern Ethiopia. Journal of African Earth Sciences, 34, 57-84. https://doi.org/10.1016/S0899-5362(01)00099-9

[13] Yihunie, T., Adachi, M. and Takeuchi, M. (2004) PT Conditions of Metamorphism in the Neoproterozoic Rocks of the Negele Area, Southern Ethiopia. Gondwana Research, 7, 489-500. https://doi.org/10.1016/S1342-937X(05)70800-5

[14] Abdelsalam, M.G. and Stern, R.J. (1996) Sutures and Shear Zones in the Arabian-Nubian Shield. Journal of African Earth Sciences, 23, 289-310. https://doi.org/10.1016/S0899-5362(97)00003-1

[15] Chater, A. (1971) The Geology of the Megado Region of Southern Ethiopia. University of Leeds, Leeds. 
[16] Gilboy, C.F. (1970) The Geology of the Gariboro Region of Southern Ethiopia. University of Leeds, Leeds.

[17] Kazmin, V. (1972) The Precambrian Geology of Ethiopia and Some Aspects of the Geology of the Mozambique Belt. BGO, 15, 27-43.

[18] Kazmin, V., Shifferaw, A. and Balcha, T. (1978) The Ethiopian Basement: Stratigraphy and Possible Manner of Evolution. Geologische Rundschau, 67, 531-546. https://doi.org/10.1007/BF01802803

[19] Ayalew, T., Bell, K., Moore, J.M. and Parrish, R.R. (1990) U-Pb and Rb-Sr Geochronology of the Western Ethiopian Shield. Geological Society of America Bulletin, 102, 1309-1316. https://doi.org/10.1130/0016-7606(1990)102<1309:UPARSG>2.3.CO;2

[20] Gerra, S. (2000) A Short Introduction to the Geology of Ethiopia. Chronicle of Mineral Research and Exploration, 540, 3-10.

[21] Gichile, S. (1992) Granulites in the Precambrian Basement of Southern Ethiopia: Geochemistry, PT Conditions of Metamorphism and Tectonic Setting. Journal of African Earth Sciences, 15, 251-263. https://doi.org/10.1016/0899-5362(92)90072-K

[22] Teklay, M., Kröner, A., Mezger, K. and Oberhänsli, R. (1998) Geochemistry, Pb-Pb Single Zircon Ages and Nd-Sr Isotope Composition of Precambrian Rocks from Southern and Eastern Ethiopia: Implications for Crustal Evolution in East Africa. Journal of African Earth Sciences, 26, 207-227. https://doi.org/10.1016/S0899-5362(98)00006-2

[23] Tadesse, G. and Allen, A. (2002) Geology and Geochemistry of the Neoproterozoic Tuludimtu Orogenic Belt, Western Ethiopia. 19th Colloquium of African Geology, El Jadida, 19-22 March 2002, 173-174.

[24] Emelyanov, E.L., Abebaw, T., Tesfaye, T. and Teweldemedhin, T. (1986) Preliminary Report on Prospecting Results of the Kenticha Rare Metal Deposit. Internal Report, Ethiopian Mineral Resource Development Corp, Ministry of Mines and Energy, Addis Ababa. (Unpublished)

[25] Kozyrev, V., Girma, K., Safonov, J., Bekele, W. and Teweldemedhin, T. (1982) Regional Geological and Exploration Work for Gold and Other Minerals in the Adola Gold Fields. Internal Report, Ethiopian Mineral Resource Development Corp, Adddis Ababa, 260 p. (Unpublished)

[26] Desta, Z., Garbarino, C. and Valera, R. (1995) Granite Pegmatite System in Kenticha (Adola, Sidamo, Ethiopia) Rare Metal Pegmatite Belt: Petrochemistry, Regional Pegmatite Zoning and Classification. SINET: Ethiopian Journal of Science, 18, 119148.

[27] Desta, Z. (1996) Mineralogical, Geochemical, Internal Structure and Metallogenetic Relationship of Granitite-Pegmatite Units in Kenticha Area (Adola, Ethiopia). Ethiopian Geoscience and Mining Engineering Association, 251-280.

[28] Küster, D., Romer, R.L., Tolessa, D., Bheemalingeswara, Zerihun, D.K.B., Melcher, F. and Oberthür, T. (2009) The Kenticha Rare-Element Pegmatite, Ethiopia: Internal Differentiation, U-Pb Age and Ta Mineralization. Mineralium Deposita, 44, 723-750.

[29] Tadesse, S. (2001) Geochemistry of the Pegmatitic Rocks and Minerals in the Kenticha Belt, Southern Ethiopia: Implication to Geological Setting. Gondwana Research, 4, 97-104. https://doi.org/10.1016/S1342-937X(05)70658-4

[30] Tadesse, S. and Desta, Z. (1996) Composition, Fractionation Trend and Zoning Accretion of the Columbite-Tantalite Group of Minerals in the Kenticha Rare-Metal Field (Adola, Southern Ethiopia). Journal of African Earth Sciences, 23, 411-431. https://doi.org/10.1016/S0899-5362(97)00010-9 
[31] Dill, H.G. (2015) Pegmatites and Aplites: Their Genetic and Applied Ore Geology. Ore Geology Reviews, 69, 417-561. https://doi.org/10.1016/j.oregeorev.2015.02.022

[32] Shearer, C.K., Papike, J.J. and Laul, J.C. (1987) Mineralogical and Chemical Evolution of a Rare-Element Granite-Pegmatite System: Harney Peak Granite, Black Hills, South Dakota. Geochimica et Cosmochimica Acta, 51, 473-486. https://doi.org/10.1016/0016-7037(87)90062-7

[33] Černý, P. (1990) Distribution, Affiliation and Derivation of Rare-Element Granitic Pegmatites in the Canadian Shield. Geologische Rundschau, 79, 183-226. https://doi.org/10.1007/BF01830621

[34] Desta, Z., Abdella, K., Admasse, A., Tsegaye, G., Solomon, T. and Nuri, M. (2003) Results of Deep Level Primary Ore Exploration for Tantalum and Niobium Deposit at Kenticha Area. Ethiopian Mineral Development Share Company, Addis Ababa, $1-60$.

[35] Ethiopian Mineral Development Enterprise (1997) Background Information on Kenticha Tantalum Development, Volume I-Internal Report.

[36] Mohammedyasin, M. (2016) Geology, Geochemistry and Genesis of Tantalite Deposit of the Primary Ore Zone of Kenticha Rare Metal Pegmatite Field, Adola Belt, Southern Ethiopia. Unpublished MSc Thesis at Addis Ababa University, Addis Ababa.

[37] Melcher, F., Graupner, T., Gäbler, H.-E., Sitnikova, M., Henjes-Kunst, F., Oberthür, T., Gerdes, A. and Dewaele, S. (2015) Tantalum-(Niobium-Tin) Mineralisation in African Pegmatites and Rare Metal Granites: Constraints from Ta-Nb Oxide Mineralogy, Geochemistry and U-Pb Geochronology. Ore Geology Reviews, 64, 667-719. https://doi.org/10.1016/j.oregeorev.2013.09.003

[38] Larsen, R.B. (2002) The Distribution of Rare-Earth Elements in K-Feldspar as Indicator of Petrogenetic Processes in Granitic Pegmatites: Examples from Two Pegmatite Fields in Southern Norway. The Canadian Mineralogist, 40, 137-151.

https://doi.org/10.2113/gscanmin.40.1.137

[39] El Bouseily, A.M. and El Sokkary, A.A. (1975) The Relation between Rb, Ba and Sr in Granitic Rocks. Chemical Geology, 16, 207-219. https://doi.org/10.1016/0009-2541(75)90029-7

[40] McDonough, W. and Sus, S. (2005) The Composition of the Earth. Chemical Geology, 120, 223-253. https://doi.org/10.1016/0009-2541(94)00140-4

[41] Küster, D., Romer, R.L., Tolessa, D., Zerihun, D. and Bheemalingeswara, K. (2007) Geochemical Evolution and Age of the Kenticha Tantalum Pegmatite, Southern Ethiopia. International Symposium on Granitic Pegmatites. The State of the Art, Porto, 6-12 May 2007, 50-51.

[42] Küster, D. (2009) Granitoid-Hosted Ta Mineralization in the Arabian-Nubian Shield: Ore Deposit Types, Tectono-Metallogenetic Setting and Petrogenetic Framework. Ore Geology Reviews, 35, 68-86. https://doi.org/10.1016/j.oregeorev.2008.09.008

[43] Poletayev, P., Verbvsky, O., Teweldemedhin, T., Musa, E., Alemayehu, B. and Manaye, Y. (1989) On a Detailed Exploration of the Weathering Mantle Upper Level Ores of the Kenticha Rare-Metal Deposits, Site No. 2. Internal Rep. EMDSC, Ministry Mines Energy, Addis Ababa. (Unpublished)

[44] Bentor, Y.K. (1985) The Crustal Evolution of the Arabo-Nubian Massif with Special Reference to the Sinai Peninsula. Precambrian Research, 28, 1-74. https://doi.org/10.1016/0301-9268(85)90074-9

[45] Stern, R.J. (1994) Arc-Assembly and Continental Collision in the Neoproterozoic African Orogen: Implications for the Consolidation of Gondwanaland. Annual Review of Earth and Planetary Sciences, 22, 319-351.

https://doi.org/10.1146/annurev.earth.22.1.319 
[46] Stern, R.J. and Hedge, C.E. (1985) Geochronologic and Isotopic Constraints on Late Precambrian Crustal Evolution in the Eastern Desert of Egypt. American Journal of Science, 285, 97-127. https://doi.org/10.2475/ajs.285.2.97

[47] Tadesse, S. (1998) Structure of Pegmatitic Bodies of the Kenticha Deposit, Adola Gold Field (Southern Ethiopia). Africa Geoscience Review, 5, 527-535.

[48] Bongiolo E.M., Renac C., de Toledo Piza, P.D., da Silva Schmitt, R. and Mexias, A.S. (2015) Origin of Pegmatites and Fluids at Ponta Negra (RJ, Brazil) during Late- to Post-Collisional Stages of the Gondwana Assembly. Lithos, 240, 259-275.

[49] Simmons, S. (2007) Pegmatite Genesis: Recent Advances and Area for Future Research. Granitic Pegmatites: The State of the Art-International Symposium, Porto, 6-12 May 2007, 4.

[50] London, D. and Morgan, G.B. (2012) The Pegmatite Puzzle. Elements, 8, 263-268. https://doi.org/10.2113/gselements.8.4.263

[51] Cameron, E.N. (1949) Internal Structure of Granitic Pegmatites, No. 2. Economic Geology Publishing Company, Littleton.

[52] Jahns, R.H. and Burnham, C.W. (1969) Experimental Studies of Pegmatite Genesis; A Model for the Derivation and Crystallization of Granitic Pegmatites. Economic Geology, 64, 843-864. https://doi.org/10.2113/gsecongeo.64.8.843

[53] Jahns, R. (1982) Internal Evolution of Pegmatite Bodies. In: Cerny, P., Ed., Granitic Pegmatites in Science and Industry, Vol. 8, Mineralogical Association of Canada, Ottawa, 293-327.

[54] Shearer, C.K., Papike, J.J. and Jolliff, B.L. (1992) Petrogenetic Links among Granites and Pegmatites in the Harney Peak Rare-Element Granite-Pegmatite System, Black Hills, South Dakota. The Canadian Mineralogist, 30, 785.

[55] Acosta-Vigil, A., London, D., VI, G.B.M. and Dewers, T.A. (2003) Solubility of Excess Alumina in Hydrous Granitic Melts in Equilibrium with Peraluminous Minerals at $700-800 \mathrm{C}$ and $200 \mathrm{MPa}$, and Applications of the Aluminum Saturation Index. Contributions to Mineralogy and Petrology, 146, 100-119. https://doi.org/10.1007/s00410-003-0486-6

[56] Černý, P., London, D. and Novák, M. (2012) Granitic Pegmatites as Reflections of Their Sources. Elements, 8, 289-294. https://doi.org/10.2113/gselements.8.4.289

[57] Neiva, A.M.R., Gomes, M.E.P., Ramos, J.M.F. and Silva, P.B. (2008) Geochemistry of Granitic Aplite-Pegmatite Sills and Their Minerals from Arcozelo Da Serra Area (Gouveia, Central Portugal). European Journal of Mineralogy, 20, 465-485. https://doi.org/10.1127/0935-1221/2008/0020-1827

[58] Černý, P., Novak, M. and Chapman, R. (1992) Effects of Sillimanite-Grade Metamorphism and Shearing on Nb-Ta Oxide Minerals in Granitic Pegmatites: Marsikov, Northern Moravia, Czechoslovakia. The Canadian Mineralogist, 30, 699-718.

[59] Černý, P. (1991) Rare-Element Granitic Pegmatites. Part I: Anatomy and Internal Evolution of Pegmatitic Deposits. Geoscience Canada, 18, 49-67.

[60] Simmons, W., Foord, E., Falster, A. and King, V. (1995) Evidence for an Anatectic Origin of Granitic Pegmatites, Western Maine, USA. Abstracts with Programs-Geological Society of America, 27, 411.

[61] Heilbron, M., Valeriano, C.M., Tassinari, C.C.G., Almeida, M., Tupinambá, J.C.H., Junior, O.S. and Trouw, R.A.J. (2008) Correlation of Neoproterozoic terranes between Ribeira Belt, SE Brazil and Its African Counterpart: Comparative Tectonic Evolution and Open Questions. In: Pankhurst, R.J., Trouw, R.A.J., de Brito Neves, B.B. and de Wit, M.J., Eds., West Gondwana: Pre-Cenozo, Geological Society, London, Vol. 295, 211-237. https://doi.org/10.1144/SP294.12 
[62] Morgan, G.B. and London, D. (1987) Alteration of Amphibolitic Wallrocks around the Tanco Rare-Element Pegmatite, Bernic Lake, Manitoba. American Mineralogist, 72, 1097-1121.

[63] Novák, M., Škoda, R., Gadas, P., Krmíček, L. and Černý, P. (2012) Contrasting Origins of the Mixed (NYF+ LCT) Signature in Granitic Pegmatites, with Examples from the Moldanubian Zone, Czech Republic. The Canadian Mineralogist, 50, 1077-1094. https://doi.org/10.3749/canmin.50.4.1077

[64] McKeough, M.A., Lentz, D.R., McFarlane, C.R.M. and Jarrod, B. (2013) Geology and Evolution of Pegmatite-Hosted U-Th \pm REE-Y-Nb Mineralization, Kulyk, Eagle, and Karin Lakes Region, Wollaston Domain, Northern Saskatchewan, Canada: Examples of the Dual Role of Extreme Fractionation and Hybridization Processes. Journal of Geosciences, 58, 321-346. https://doi.org/10.3190/jgeosci.153

Submit or recommend next manuscript to SCIRP and we will provide best service for you:

Accepting pre-submission inquiries through Email, Facebook, LinkedIn, Twitter, etc. A wide selection of journals (inclusive of 9 subjects, more than 200 journals)

Providing 24-hour high-quality service

User-friendly online submission system

Fair and swift peer-review system

Efficient typesetting and proofreading procedure

Display of the result of downloads and visits, as well as the number of cited articles

Maximum dissemination of your research work

Submit your manuscript at: http://papersubmission.scirp.org/

Or contactijg@scirp.org 